\title{
Polymorphism of the Signaling Molecule c-di-GMP
}

\author{
Zhaoying Zhang, Seho Kim, Barbara L. Gaffney, and Roger A. Jones* \\ Department of Chemistry and Chemical Biology, 610 Taylor Road, Rutgers, The State University of \\ New Jersey, Piscataway, New Jersey 08854
}

\begin{abstract}
Using UV, CD, and NMR, we demonstrate that the important bacterial signaling molecule involved in biofilm formation, cyclic diguanosine monophosphate (c-di-GMP), exists as a mixture of five different but related structures in an equilibrium that is sensitive both to its concentration and to the metal present. At the lower concentrations used for UV and CD work $(0.05-0.5 \mathrm{mM}) \mathrm{Li}^{+}, \mathrm{Na}^{+}$, $\mathrm{Cs}^{+}$, and $\mathrm{Mg}^{2+}$ favor a bimolecular self-intercalated structure, while $\mathrm{K}^{+}, \mathrm{Rb}^{+}$, and $\mathrm{NH}_{4}^{+}$favor formation of one or more guanine quartet complexes as well. At the higher NMR concentrations $(\sim 30 \mathrm{mM})$, the bimolecular structures associate and rearrange to a mixture of all-syn and all-anti tetramolecular and octamolecular quartet complexes. With $\mathrm{K}^{+}$the octamolecular complexes predominate, while with $\mathrm{Li}^{+}$the tetramolecular and octamolecular quartet complexes are present in approximately equal amounts, along with the bimolecular structure. We also find that both guanine amino groups in c-di-GMP are essential for formation of the quartets, since substitution of inosine for one guanosine allows formation of only the bimolecular structure. Further, two molecules of cdi-GMP tethered together are constrained in such a way that limits their ability to form these quartet complexes. The polymorphism we describe may provide different options for this signaling molecule when performing its functions in a bacterial cell, with $\mathrm{K}^{+}$and its own local concentration controlling the equilibrium.
\end{abstract}

\section{Introduction}

The importance of cyclic diguanosine monophosphate, c-di-GMP, 1 (Fig. 1), as a ubiquitous intracellular bacterial signaling molecule responsible for regulating biofilm formation, cell differentiation, and a variety of pathogenic processes has recently been recognized. ${ }^{1}$ Biofilms are complex, multicellular aggregations of bacteria attached to surfaces and encased in a matrix of polysaccharides. ${ }^{2}$ Formation of such communities is an ancient adaptation that allows bacteria to survive a range of environmental challenges in a protected state. The medical, industrial, and environmental threat of biofilms for human life is profound, since they are far more resistant than free-living bacteria to antimicrobials as well as to natural host defense mechanisms. ${ }^{3}$ Not only are antibiotics typically ineffective in treating chronic infections protected by biofilms, but low doses of aminoglycosides have recently been shown to actually induce biofilm formation in Pseudomonas aeruginosa and Escherichia coli through a mechanism controlled by c-di-GMP. ${ }^{4}$

Specific c-di-GMP cyclases with GGDEF domains in many different bacteria are responsible for formation of c-di-GMP from two molecules of GTP, 5,6 and a crystal structure has been determined for the cyclase from Caulobacter crescentus. ${ }^{7}$ c-di-GMP levels in P. aeruginosa, E. coli, Vibrio cholerae, Salmonella enterica, and Yersinia pestis have been shown to be inversely regulated by such cyclases along with specific phosphodiesterases associated with EAL domains. ${ }^{8,9}$ Many bacterial proteins contain both GGDEF and EAL domains, ${ }^{10}$ and in 
C. crescentus, a phosphodiesterase with an active EAL domain has recently been found to be regulated by the binding of GTP to its neighboring catalytically inactive GGDEF domain. ${ }^{11}$ Thus, control of c-di-GMP concentrations in bacteria is extremely complex, and may also involve gradients as well as spatial localization. ${ }^{12}$

As an intracellular signaling molecule, c-di-GMP is known to regulate cell mobility, 5 production of adhesive components, 8,13 and other features of multicellular behavior in response to environmental cues. ${ }^{12}$ It also plays an important role in the pathogenic virulence of Salmonella in mice ${ }^{14}$ and virulence gene expression in V. cholerae. ${ }^{15}$ A group of extracellular signaling molecules termed autoinducers also regulate biofilm formation and virulence in bacteria through a process known as quorum sensing. ${ }^{16}$ Examples include acyl homoserine lactones, ${ }^{17}$ modified oligopeptides, ${ }^{18}$ modified quinolones, ${ }^{19}$ and a possible universal autoinducer, AI-2. ${ }^{20}$ The integration of these extracellular signals with the c-di-GMP pathways is only now being explored. ${ }^{21}$ To date the molecular mechanisms for these complex pathways remain unknown and represent a major challenge. Although several crystal structures for c-di-GMP published some time ago revealed a self-intercalated arrangement of two molecules, 22,23 structures in solution have not been determined. Understanding the structure and behavior of c-di-GMP in solution would provide valuable insight into how it might interact with the multitude of other molecules involved in its pathways.

We recently reported a new method for the efficient synthesis of c-di-GMP, $\mathbf{1}$, as well as UV, $\mathrm{CD}$, and 1D NMR results that demonstrated a monovalent metal ion-dependent polymorphism. ${ }^{24} \mathrm{We}$ found evidence for a stacked structure with $\mathrm{Li}^{+}$and $\mathrm{Na}^{+}$, and the suggestion of a quartet structure with $\mathrm{K}^{+}$. We now describe $\mathrm{UV}$ and $\mathrm{CD}$ data for additional metals that further define these forms, and we have initiated more detailed structural studies using 2D NMR. We have also synthesized a mixed dimer containing guanosine and inosine, c-GMP-IMP, 2 (Fig. 1), and found that the elimination of one amino group precluded quartet formation. Further, in an effort to evaluate the consequences of molecular constraints on the behavior of $\mathbf{1}$, we have connected two units together with a flexible oligoethylene oxide tether of two different lengths, 3a where $\mathrm{n}=4$ and $\mathbf{3 b}$ where $\mathrm{n}=12$ (Fig. 1). This constraint also has a significant effect on the equilibrium, shifting it substantially to the self-intercalated structure. The new data support the existence of five distinct but related complexes for $\mathbf{1}$ that exist in an equilibrium that is sensitive to both concentration and the metal present.

\section{Experimental Procedures}

\section{Synthesis}

The detailed procedures for synthesis of c-GMP-IMP, 2, and the tethered c-di-GMP, 3a and $\mathbf{3 b}$, are described in the Supporting Information.

UV

UV melting curves were obtained on an Aviv 14 UV Spectrophotometer using 1, 2, 5, and 10 $\mathrm{mm}$ path length cells. After preparation in the appropriate buffer, samples were degassed, heated to $80^{\circ} \mathrm{C}$, allowed to cool slowly to room temperature, and then placed in a refrigerator for at least 15 hours. UV absorbance spectra were obtained using samples in the $1 \mathrm{~mm}$ cells.

\section{CD}

CD spectra were obtained on an Aviv Model 60DS CD Spectrometer using a $1 \mathrm{~mm}$ cell. The samples were prepared as described for UV. For time-dependent CD experiments, data at a given wavelength were acquired immediately after the temperature was changed. The effective temperature change rate of the instrument was $10^{\circ} \mathrm{C} / \mathrm{min}$. 
1D NMR

The ${ }^{31} \mathrm{P}$ NMR spectra were acquired on a Varian Mercury $300 \mathrm{MHz}$ spectrometer and referenced to $10 \%$ phosphoric acid in $\mathrm{D}_{2} \mathrm{O}$; the ${ }^{1} \mathrm{H}$ NMR spectra were acquired on a Varian Unity $400 \mathrm{MHz}$ spectrometer.

\section{D NMR}

2D NOESY (nuclear Overhauser effect spectroscopy), HMBC (heteronuclear multiple bond correlation), and HMQC (heteronuclear multiple quantum coherence) spectra were acquired at $25{ }^{\circ} \mathrm{C}$ on a Varian Inova $500 \mathrm{MHz}$ spectrometer. NOESY data were collected by 4096 (t2) times 512 (t1) complex data points with spectral widths of $8000 \mathrm{~Hz}$ in both dimensions and transformed to spectra with 2048 (D1) times 1024 (D2) real data points. The mixing time for NOESY spectra was $150 \mathrm{~ms}$, the number of scans per each $\mathrm{t} 1$ increment was 16 , and the relaxation delay for each scan was $2 \mathrm{~s}$. Natural abundance ${ }^{1} \mathrm{H}_{-}{ }^{13} \mathrm{C}$ HMQC and $\mathrm{HMBC}$ were acquired by 2048 (t2) times 256 (t1) complex points with spectral widths of $8000 \mathrm{~Hz}$ (t2) and $18000 \mathrm{~Hz}$ (t1) and transformed to spectra with 2048 (D1) times 512 (D2) real points. The DEPT transfer delay in $\mathrm{HMQC}$ was chosen as $0.5 /{ }^{1} \mathrm{~J}_{\mathrm{HC}}$ with ${ }^{1} \mathrm{~J}_{\mathrm{HC}}=150 \mathrm{~Hz}$ and the transfer delay in HMBC was chosen as $0.5{ }^{2,3} \mathrm{~J}_{\mathrm{HC}}\left({ }^{2,3} \mathrm{~J}_{\mathrm{HC}}=12 \mathrm{~Hz}\right)$ which is close to multiples of $0.5 /{ }^{1} \mathrm{~J}_{\mathrm{HC}}$ to suppress HMQC peaks. The HMBC pulse sequence and data collection mode (phase sensitive mode) were the same as HMQC with decoupling during ${ }^{1} \mathrm{H}$ data acquisition. The number of scans was 32 for HMQC and 256 for HMBC and the relaxation delay for each scan was 1 s. All 2D NMR spectra used $1 \mathrm{~s}^{1} \mathrm{H}$ pre-saturation during the relaxation delay to suppress water.

\section{Results}

\section{1. c-di-GMP, 1}

UV Melts (Fig. 2)-UV melting profiles at $250 \mathrm{~nm}$ for four different concentrations of $\mathbf{1}$ with $\mathrm{Mg}^{2+}$ (Fig 2A) show single conformational transitions similar to those with $\mathrm{Li}^{+}$and $\mathrm{Na}^{+}, 24$ but reflect a more thermally stable structure. First derivative curves for the most concentrated sample with each metal (Supporting Information) show one clear maximum, with $\mathrm{T}_{\max }$ values of $8{ }^{\circ} \mathrm{C}$ for $\mathrm{Na}^{+}, 10{ }^{\circ} \mathrm{C}$ for $\mathrm{Li}^{+}$, and $45^{\circ} \mathrm{C}$ for $\mathrm{Mg}^{2+}$. The concentration dependence of the transitions with these metals indicates that the structured forms have a molecularity of at least $2{ }^{25}$ Further, the significant hypochromicity of the UV curves indicates that stacking of the guanines plays an important role in the structure.

The UV melting profile at $250 \mathrm{~nm}$ for the $\mathrm{Rb}^{+}$form of $\mathbf{1}$ (Fig. 2B, blue) shows two broad conformational transitions, somewhat similar to those of the $\mathrm{K}^{+}$form ${ }^{24}$ (included in Fig. 2B, black), but with lower stabilities. $\mathrm{T}_{\max }$ values from first derivative curves are $30{ }^{\circ} \mathrm{C} / 54{ }^{\circ} \mathrm{C}$ for $\mathrm{K}^{+}$and $<5{ }^{\circ} \mathrm{C} / 20^{\circ} \mathrm{C}$ for $\mathrm{Rb}^{+}$. Although the UV melting profile for the $\mathrm{NH}_{4}{ }^{+}$form appears to show a single conformational transition (Fig. $2 \mathrm{~B}$, red), its first derivative curve shows two broad overlapping maxima, with $\mathrm{T}_{\max }$ values of $10^{\circ} \mathrm{C} / 20^{\circ} \mathrm{C}$.

The UV spectrum of the $\mathrm{K}^{+}$form of $\mathbf{1}$ displays a distinct shoulder between 295 and $305 \mathrm{~nm}$ that is not present in the $\mathrm{Li}^{+}, \mathrm{Na}^{+}$or $\mathrm{Mg}^{2+}$ forms, and is weak in the $\mathrm{Rb}^{+}$and $\mathrm{NH}_{4}+$ forms (Supporting Information). Since similar shoulders were found to be characteristic of intramolecular guanine quartet structures formed by a series of oligodeoxynucleotides, ${ }^{26}$ we now report UV melting experiments at $305 \mathrm{~nm}$ for a series of three $\mathrm{K}^{+}$samples with different concentrations (Fig. 2C). As seen with the quartet-forming oligonucleotides, ${ }^{26}$ the profiles at $305 \mathrm{~nm}$ display hyperchromic changes rather than the typical hypochromic changes seen at $250 \mathrm{~nm}$. Together, the UV results support the presence of one or more additional structures for 1 with $\mathrm{K}^{+}$and $\mathrm{Rb}^{+}$that contain guanine quartets. Further, since intramolecular guanine quartet oligonucleotides that exhibit hyperchromic behavior all contain some guanines with syn 
conformations, ${ }^{27}$ by extension, at least one of the quartet structures of $\mathbf{1}$ in $\mathrm{K}^{+}$and $\mathrm{Rb}^{+}$may also contain some syn guanines.

CD Spectra (Fig. 3)-A CD spectrum of the $\mathrm{Mg}^{2+}$ form of $\mathbf{1}$ (Fig. 3A, green) closely resembles those of $\mathrm{Li}^{+}$(red) ${ }^{24}$ and $\mathrm{Na}^{+}$(blue). ${ }^{24}$ Upon heating to $75^{\circ} \mathrm{C}$, the bands all quickly diminish to small residual values (not shown). The positive band at $257 \mathrm{~nm}$ and the negative band at $281 \mathrm{~nm}$ form a pattern that is inverted relative to right-handed DNA and RNA, but is similar to CD spectra of cyclic dithymidine monophosphate, ${ }^{28} 5^{\prime}$-GMP and 3'-GMP in $0.1 \mathrm{M}$ $\mathrm{K}^{+, 29}$ left-handed $5^{\prime}-5^{\prime} \mathrm{GpG},{ }^{29}$ left-handed $\mathrm{Z}$ DNA,${ }^{30}$ and diadenosine and diguanosine $5^{\prime}$, $5^{\prime \prime \prime}$-oligophosphates. ${ }^{31}$ For the $\mathrm{Li}^{+}, \mathrm{Na}^{+}$and $\mathrm{Mg}^{2+}$ forms of $\mathbf{1}$, the pattern for the 257 and 281 $\mathrm{nm}$ bands is consistent with the possibility of a left-handed alignment of the guanine transition moments.

The $\mathrm{CD}$ spectrum that we previously reported for the $\mathrm{K}^{+}$form of $\mathbf{1}$ displays additional bands at $215 \mathrm{~nm}$ (strong) and $309 \mathrm{~nm}$ (weak) ${ }^{24}$ (Fig. 3B, black). Further, its central positive band appears at $252 \mathrm{~nm}$ rather than $257 \mathrm{~nm}$. We now report CD spectra for $\mathrm{Rb}^{+}$(blue), $\mathrm{Cs}^{+}$(green), and $\mathrm{NH}_{4}{ }^{+}$(red) forms (Fig. 3B). The presence of a similar $215 \mathrm{~nm}$ band for the $\mathrm{Rb}^{+}$form (although only half the intensity), but none for the $\mathrm{Cs}^{+}$form, demonstrates the same dependence

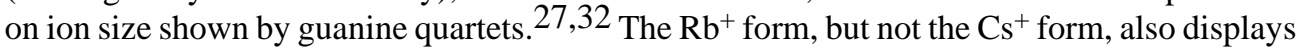
a shift to lower wavelength for the central positive band, although only about half as much as for the $\mathrm{K}^{+}$form. The $\mathrm{NH}_{4}{ }^{+}$form shows a weak $215 \mathrm{~nm}$ band and a small shift of its central band. Positive $\mathrm{CD}$ bands near $300 \mathrm{~nm}$ have been observed for oligodeoxynucleotides with intramolecular quartet structures that have a mixture of syn and anti orientations, while those with intermolecular quartets that are all anti do not have this $300 \mathrm{~nm}$ band. 27,33

We have previously reported the slow appearance and disappearance of the 215 and $309 \mathrm{~nm}$ bands for the $\mathrm{K}^{+}$form of $\mathbf{1}(\sim 20 \mathrm{hr}) .{ }^{24} \mathrm{We}$ now report similar behavior for the $\mathrm{Rb}^{+}$form, where nearly $8 \mathrm{hr}$ are required for the full appearance of the $215 \mathrm{~nm}$ band upon cooling from $75^{\circ} \mathrm{C}$ to $5{ }^{\circ} \mathrm{C}$ (Fig. 4A, blue). Further, a similar cooling curve for the $254 \mathrm{~nm}$ band (red) displays a fast increase over minutes to a maximum value, followed by a slow decrease to a somewhat smaller value. This slow decrease of the $254 \mathrm{~nm}$ band correlates with the slow increase of the $215 \mathrm{~nm}$ band, and reflects the shifting of the central positive band that presumably occurs upon quartet formation. Our previously reported data for the $\mathrm{K}^{+}$form at $250 \mathrm{~nm}$ upon cooling 24 also shows a fast increase followed by a similar slow decrease that is less pronounced than with $\mathrm{Rb}^{+}$. These results support the initial formation of a bimolecular stacked structure in $\mathrm{K}^{+}$and $\mathrm{Rb}^{+}$, which then undergoes a slow association and rearrangement to one or more quartet structures.

We had already shown the slow loss of the 215 and $250 \mathrm{~nm}$ bands upon heating the $\mathrm{K}^{+}$form from $5{ }^{\circ} \mathrm{C}$ to $40{ }^{\circ} \mathrm{C}(\sim 20 \mathrm{hr})$, consistent with both bands being associated with the quartet structure. ${ }^{24}$ Heating the $\mathrm{Rb}^{+}$form from $5{ }^{\circ} \mathrm{C}$ to $40{ }^{\circ} \mathrm{C}$ also shows a slow loss of the 215 and $254 \mathrm{~nm}$ bands (Fig. 4B), but over only about 10 minutes, consistent with the lower thermal stability of the $\mathrm{Rb}^{+}$quartet structure.

NMR Spectra-We previously reported $1{ }^{1}{ }^{1} \mathrm{H}$ and ${ }^{31} \mathrm{P}$ NMR spectra for the $\mathrm{Li}^{+}, \mathrm{Na}^{+}$, and $\mathrm{K}^{+}$forms of $\sim 35 \mathrm{mM}$ samples of $\mathbf{1}$ in $0.1 \mathrm{M} \mathrm{LiCl}, \mathrm{NaCl}$, or $\mathrm{KCl}$, respectively, at $\mathrm{pH} 7{ }^{24}$ The data for the $\mathrm{K}^{+}$form were consistent with two different types of quartet structures that were both stable even at $55{ }^{\circ} \mathrm{C}$ : one type $(\sim 50 \%)$ displayed two guanine $\mathrm{H} 8$ resonances and two upfield ${ }^{31} \mathrm{P}$ resonances, and another type $(\sim 44 \%)$ displayed only one $\mathrm{H} 8$ resonance and only one downfield ${ }^{31} \mathrm{P}$ resonance. Two addi tional minor ( $\sim 2$ and $\left.4 \%\right) \mathrm{H} 8$ and ${ }^{31} \mathrm{P}$ resonances were also present. ${ }^{31} \mathrm{P}$ NMR spectra at $5{ }^{\circ} \mathrm{C}$ for the $\mathrm{Li}^{+}$and $\mathrm{Na}^{+}$forms of $\mathbf{1}$ also displayed upfield and downfield resonances, but in more complex patterns. ${ }^{24}$ These signals had significantly diminished at $55^{\circ} \mathrm{C}$, leaving a prominent central resonance near $-1.0 \mathrm{ppm} .{ }^{1} \mathrm{H}$ NMR spectra 
at $5{ }^{\circ} \mathrm{C}$ for the $\mathrm{Li}^{+}$form showed six guanine $\mathrm{H} 8$ resonances. These results are consistent with the presence of a group of structures having lower stabilities than those of the $\mathrm{K}^{+}$form. In spite of their different stabilities, the $\mathrm{Li}^{+}, \mathrm{Na}^{+}$, and $\mathrm{K}^{+}$forms in $90 \% \mathrm{H}_{2} \mathrm{O}$ all displayed ${ }^{1} \mathrm{H}$ resonances near $11 \mathrm{ppm}$ consistent with hydrogen bonded guanine $\mathrm{H} 1 \mathrm{~s}$, as well as broad resonances near 9 and $6.5 \mathrm{ppm}$ consistent with hydrogen bonded and non-hydrogen bonded guanine amino protons, respectively. ${ }^{34}$ As described more fully in the Discussion section, these previous1D NMR results and new 2D NMR data introduced below for both the $\mathrm{K}^{+}$and $\mathrm{Li}^{+}$forms of 1 support the presence in varying amounts of five different but related structures shown in the cartoons at the bottom of Figure 5: one bimolecular self-intercalated structure (shown in more detail at the top left of Figure 5), two tetramolecular and two octamolecular structures, all of which contain guanine quartets (shown at the top right of Figure 5, with the $\mathrm{H} 8$ to $\mathrm{H}$-bonded amino NOE highlighted in red). The 2D NMR data described below demonstrate that the larger complexes exist in both all-syn and all-anti conformations.

The 1D spectrum of a $37 \mathrm{mM}$ sample of the $\mathrm{K}^{+}$form of $\mathbf{1}$ in $\mathrm{KCl}$ at $\mathrm{pH} 7$ at $25^{\circ} \mathrm{C}$ is shown at the top of Figure 6, with a portion of its superimposed ${ }^{1} \mathrm{H}_{-}{ }^{13} \mathrm{C}$ HMBC/HMQC spectrum at the center, and a portion of its ${ }^{1} \mathrm{H}-{ }^{1} \mathrm{H}$ NOESY spectrum at the bottom. Region A in the NOESY spectrum shows a set of $\mathrm{H} 8$ to $\mathrm{H} 1^{\prime}$ crosspeaks. The three major $\mathrm{H} 8$ resonances show crosspeaks to H1' resonances, of which one is significantly stronger than the other two. The different NOE intensities are consistent with a syn guanosine conformation for the stronger NOE and anti conformations for the weaker NOEs. 35 The $\mathrm{H} 8$ resonances at 7.75, 8.20, and $7.95 \mathrm{ppm}$, and the $\mathrm{H} 1^{\prime}$ resonances at $6.05,6.19$, and $5.77 \mathrm{ppm}$, are therefore labeled $\mathrm{O} s, \mathrm{O} a$, and $\mathrm{O} a^{\prime}$ for octamolecular/syn and anti, respectively. There are no crosspeaks between the syn and anti resonances, while crosspeaks are observed between the two anti resonances. Of the two minor $\mathrm{H} 8$ resonances, one shows a stronger crosspeak to the $\mathrm{H} 1$ ' region than the other, again indicating syn and anti conformations. The $\mathrm{H} 8$ resonances at 7.85 and $8.26 \mathrm{ppm}$, and the $\mathrm{H} 1^{\prime}$ resonances at 6.12 and $5.96 \mathrm{ppm}$ are therefore labeled $\mathrm{T} s$ and $\mathrm{T} a$, for tetramolecular/syn and anti, respectively. These NOESY crosspeaks had the same positive sign as the auto-peaks due to negative NOE enhancements, and built up quite fast at a mixing time of $150 \mathrm{~ms}$, which indicates that the molecular species giving rise to them are in the slow tumbling regime. ${ }^{36}$ Since neither the monomeric $(\mathrm{MW}=689)$ nor the dimeric $(\mathrm{MW}=1378)$ forms of $\mathbf{1}$ in water are large enough to generate strong negative NOE enhancements, our data suggest that the four species present in this sample with $\mathrm{K}^{+}$are larger than the bimolecular form.

Region $\mathrm{B}$ in the $\mathrm{HMBC} / \mathrm{HMQC}$ confirms the assignments, since the $\mathrm{H} 1$ ' resonances labeled $\mathrm{O} s$ and $\mathrm{T} s$ show stronger crosspeaks to their $\mathrm{C} 4$ than to their $\mathrm{C} 8$ resonances, while the $\mathrm{H} 1^{\prime}$ resonances labeled $\mathrm{O} a$ and $\mathrm{O} a^{\prime}$ do not show crosspeaks to their $\mathrm{C} 4$ but do to their $\mathrm{C} 8$ resonances. Such differences have been shown to support a syn assignment for the former and an anti assignment for the latter. ${ }^{37}$

The HMBC/HMQC spectrum also allows assignment of the amido H1 resonances, as shown in Region C. The large downfield $\mathrm{H} 1$ resonance at $11.27 \mathrm{ppm}(\mathrm{Os})$ correlates only with the syn $\mathrm{H} 8$ resonance $\mathrm{O} s$, while the pair of large upfield $\mathrm{H} 1$ resonances at $11.18 \mathrm{ppm}(\mathrm{O} a$ and $\mathrm{O} a$ ') both correlate only with the two anti $\mathrm{H} 8$ resonances, $\mathrm{O} a$ and $\mathrm{O} a$ '. From Region $\mathrm{D}$ in the NOESY spectrum, the broad hydrogen bonded amino resonances can then be assigned in terms of syn and anti. The syn $\mathrm{H} 1$ resonance $\mathrm{O}$ s correlates only with the more upfield hydrogen bonded amino resonance at $8.81 \mathrm{ppm}$ (labeled $s$ ) and the anti $\mathrm{H} 1$ resonances $\mathrm{O} a$ and $\mathrm{O} a^{\prime}$ correlate with the more downfield hydrogen bonded amino resonance at $9.45 \mathrm{ppm}$ (labeled a). The minor downfield $\mathrm{H} 1$ resonance at $11.42 \mathrm{ppm}$, labeled Ts, $a$ since it presumably represents these two overlapping resonances, shows a crosspeak to the region of the syn amino resonance at $8.81 \mathrm{ppm}$. 
Since in a given quartet, each hydrogen bonded amino is close to the $\mathrm{H} 8$ of its neighbor (Figure 5 ), the pattern of their NOE crosspeaks can define the arrangement of syn and anti conformations within each quartet. 38,39 Region $\mathrm{E}$ in the NOESY spectrum shows that the broad anti hydrogen bonded amino region $(a)$ has crosspeaks only to the two anti $\mathrm{H} 8$ resonances $\mathrm{O} a$ and $\mathrm{O} a^{\prime}$, and the broad syn hydrogen bonded amino region $(s)$ has a crosspeak only to the single syn $\mathrm{H} 8$ resonance $\mathrm{O}$. Thus we conclude that with $\mathrm{K}^{+}$, c-di-GMP exists primarily as two major different quartet-containing species, with the $\mathrm{O} a / \mathrm{O} a^{\prime}$ structure being all-anti and the $\mathrm{O} s$ quartet structure being all-syn. The different intensities of the $\mathrm{O} s$ and $\mathrm{O} a$ resonances do not support the presence of a mixed species with one anti quartet and one syn quartet. All-anti quartets are well known in parallel guanine-containing oligodeoxynucleotides, 27,32 and allsyn quartets have been found in lipophilic guanine quartet assemblies. 38,40

A 1D NMR spectrum of a $33 \mathrm{mM}$ sample of the $\mathrm{Li}^{+}$form of $\mathbf{1}$ in $0.1 \mathrm{M} \mathrm{LiCl}$ at $\mathrm{pH} 7$ at $25^{\circ} \mathrm{C}$ is shown at the top of Figure 7, with a portion of its superimposed ${ }^{1} \mathrm{H}_{-}{ }^{13} \mathrm{C} \mathrm{HMBC} / \mathrm{HMQC}$ spectrum at the center and a portion of its ${ }^{1} \mathrm{H}_{-}{ }^{1} \mathrm{H}$ NOESY spectrum at the bottom. Although the relative intensities of the resonances are quite different from those of the $\mathrm{K}^{+}$form, the $2 \mathrm{D}$ spectra are strikingly similar. Region A in the NOESY spectrum shows significant crosspeaks from the two most upfield $\mathrm{H} 8$ resonances (Ts at 7.83 and $\mathrm{O} s$ at $7.74 \mathrm{ppm}$ ) to $\mathrm{H} 1$ ' resonances, but weak crosspeaks from the three more downfield $\mathrm{H} 8$ resonances ( $\mathrm{T} a$ at 8.25, $\mathrm{O} a$ at 8.19, and $\mathrm{O} a^{\prime}$ at $7.95 \mathrm{ppm}$ ) to $\mathrm{H}^{\prime}$ resonances. These NOE crosspeaks were also positive with strongly negative NOE enhancements, similar to those with $\mathrm{K}^{+}$. However, no crosspeak is seen for the sixth resonance at $7.90 \mathrm{ppm}$, labeled $\mathrm{B} a$ for bimolecular/anti. These results indicate the presence of the same syn and anti structures as with the $\mathrm{K}^{+}$form, although in more similar amounts, and with one additional structure. The $\mathrm{HMBC} / \mathrm{HMQC}$ spectrum again confirms these assignments, as shown in Region B. Further, for the sixth $\mathrm{H} 8$ resonance at $7.90 \mathrm{ppm}(\mathrm{B} a)$, a crosspeak is seen between its corresponding $\mathrm{H}^{\prime}$ resonance at $5.84 \mathrm{ppm}$ to its $\mathrm{C} 8$, but not to its $\mathrm{C} 4$ resonance, indicating this additional structure has an anti conformation.

Region $\mathrm{C}$ of the $\mathrm{HMBC} / \mathrm{HMQC}$ spectrum again allows assignment of the amido $\mathrm{H} 1$ resonances. The most downfield $\mathrm{H} 1$ resonance at $11.38 \mathrm{ppm}(\mathrm{T} a)$ correlates only with the $\mathrm{H} 8$ resonance $\mathrm{T} a$ at $8.25 \mathrm{ppm}$; the center two $\mathrm{H} 1$ resonances at $11.36 \mathrm{ppm}$ and $11.23 \mathrm{ppm}$ (Ts and $\mathrm{O} s$ ) correlate with $\mathrm{H} 8$ resonances Ts at $7.83 \mathrm{ppm}$ and $\mathrm{O} s$ at $7.74 \mathrm{ppm}$; and the upfield $\mathrm{H} 1$ resonance at 11.14 $\operatorname{ppm}\left(\mathrm{O} a, a^{\prime}\right)$ correlates with $\mathrm{H} 8$ resonances $\mathrm{O} a$ at $8.19 \mathrm{ppm}$ and $\mathrm{O} a^{\prime}$ at $7.95 \mathrm{ppm}$. From Region $\mathrm{D}$ in the NOESY spectrum, the hydrogen bonded amino resonances again can be assigned in terms of syn and anti. The anti $\mathrm{H} 1$ resonance Ta correlates with the more downfield hydrogen bonded amino region at $9.42 \mathrm{ppm}(a)$; the $\operatorname{syn} \mathrm{H} 1$ resonance Ts correlates with the more upfield hydrogen-bonded amino region at $8.85 \mathrm{ppm}(s)$; the syn resonance Os correlates with the $s$ amino region; and the anti $\mathrm{H} 1$ resonance $\mathrm{O} a$ correlates with the $a$ amino region. Region $\mathrm{E}$ in the NOESY spectrum shows two crosspeaks for the broad syn hydrogen bonded amino region $(s)$, one to the $\mathrm{H} 8$ resonance $\mathrm{O} s$ and one to the $\mathrm{H} 8$ resonance Ts. The anti hydrogen-bonded amino $(a)$ is apparently too weak to show analogous crosspeaks. These data are again consistent with an $\mathrm{O} a / \mathrm{O} a^{\prime}$ quartet structure that is all-anti and an Os quartet structure that is all-syn.

The NOESY data described above suggest that the two major and the two minor species with $\mathrm{K}^{+}$all have molecular weights larger than the bimolecular form. In order to obtain additional information, NMR diffusion experiments were performed. The data (Supporting Information) show that with $\mathrm{K}^{+}$, the translational diffusion rates of the two major forms, $\mathrm{O} a$ and $\mathrm{O} s$, are similar to each other, but smaller than those of the two minor forms, Ta and Ts, which are also similar to each other. These results demonstrate that $\mathrm{O} a$ and $\mathrm{O} s$ have a higher molecular weight than $\mathrm{T} a$ and $\mathrm{T} s$. The measured diffusion rates of these four species agree well with the published range of DNA diffusion rates. ${ }^{41}$ Diffusion data for the $\mathrm{Li}^{+}$form show a similar pattern in that the rates for $\mathrm{T} a$ and $\mathrm{T} s$ are larger than those for $\mathrm{O} a$ and $\mathrm{O} s$. The rate for the fifth form, $\mathrm{B} a$, was considerably larger than any of the other species, demonstrating a smaller molecular weight 
that is consistent with a bimolecular complex. The absolute values of the rates for the analogous species in the two samples are slightly different, perhaps because the samples are not identical.

These new UV, CD, and NMR results together present a compelling case for the presence of a mixture of five different structures that $\mathbf{1}$ can adopt, whose ratio is both metal and concentration-dependent. As discussed more fully below, a bimolecular structure $(\mathrm{B} a)$ is dominant with $\mathrm{Li}^{+}, \mathrm{Na}^{+}, \mathrm{Cs}^{+}$, and $\mathrm{Mg}^{2+}$ at dilute concentrations of $\mathbf{1}$, but is accompanied by one or more quartet structures with $\mathrm{K}^{+}$and $\mathrm{Rb}^{+}$. At the higher NMR concentrations, with $\mathrm{K}^{+}$ the bimolecular structures associate and rearrange primarily to two stable higher molecular weight quartet structures, one all-syn $(\mathrm{O} s)$ and one all-anti $(\mathrm{O} a)$, with two minor lower molecular weight quartet structures also present, $\mathrm{T} s$ and $\mathrm{T} a$. With $\mathrm{Li}^{+}$, the bimolecular structure $(\mathrm{B} a)$ predominates, but both quartet structures $(\mathrm{O} a, \mathrm{O} s, \mathrm{~T} a$, and $\mathrm{T} s)$ are also present.

\section{C-GMP-IMP, 2}

We have now synthesized a mixed cyclic dimer containing one guanosine and one inosine, 2 (Figure 1), by a method similar to what we previously reported for $1{ }^{24}$ In brief, an intermolecular coupling using phosphoramidite chemistry was followed by an H-phosphonate cyclization, with the $\mathrm{H}$-phosphonate group also serving as a 3' protecting group during the initial coupling. The detailed procedures are described in the Supporting Information. We describe below UV, CD, and NMR spectra for this molecule that has one fewer amino groups than $\mathbf{1 .}$

UV Melts (Fig 8A)-UV melting profiles at $250 \mathrm{~nm}$ for different concentrations of $\mathbf{2}$ with both $\mathrm{Li}^{+}$and $\mathrm{K}^{+}$show single concentration-dependent conformational transitions that are identical for the two cations and reflect a more stable structure than the $\mathrm{Li}^{+}$form of $\mathbf{1}$. The $\mathrm{T}_{\max }$ values of the most concentrated samples of both forms of $\mathbf{2}$ were found to be $18^{\circ} \mathrm{C}$, while the $\mathrm{T}_{\max }$ for the $\mathrm{Li}^{+}$form of $\mathbf{1}$ was only $10^{\circ} \mathrm{C}$. These results suggest that loss of one of the guanine amino groups prevents formation of quartet structures in $\mathrm{K}^{+}$, but allows a bimolecular stacked structure.

CD Spectra (Fig. 8B)-CD spectra for the $\mathrm{Li}^{+}$and $\mathrm{K}^{+}$forms of $\mathbf{2}$ are nearly identical, and display much lower intensities than the $\mathrm{Li}^{+}$form of $\mathbf{1}$, perhaps due to the different absorption properties of inosine. The lack of any bands near 215 and $305 \mathrm{~nm}$ supports the absence of quartet structures.

NMR Spectra-The 1D NMR spectra for $61 \mathrm{mM}$ samples of the $\mathrm{Li}^{+}$and $\mathrm{K}^{+}$forms of 2 at 5, 30 , and $55^{\circ} \mathrm{C}$ (Supporting Information) are much simpler than those for $\mathbf{1}$. Both ${ }^{31} \mathrm{P}$ NMR spectra of 2 at $5{ }^{\circ} \mathrm{C}$ show only two resonances near $-1.5 \mathrm{ppm}$, one for each of the different phosphates in the molecule. Neither of the ${ }^{1} \mathrm{H}$ NMR spectra in $90 \% \mathrm{H}_{2} \mathrm{O}$ at $5{ }^{\circ} \mathrm{C}$ shows $\mathrm{H} 1$ resonances near $11 \mathrm{ppm}$ or amino resonances near 9 and $6.5 \mathrm{ppm}$, demonstrating the exchange of these protons with solvent. Further, single sharp resonances are present for the guanine $\mathrm{H} 8$ and the inosine $\mathrm{H} 8$ and $\mathrm{H} 2$. As seen in Figure 9, the ${ }^{1} \mathrm{H}-{ }^{1} \mathrm{H}$ NOESY spectrum for 2 with $\mathrm{K}^{+}$ does not show crosspeaks between the $\mathrm{H} 8$ and $\mathrm{H}_{1}$ resonances, but the ${ }^{1} \mathrm{H}_{-}{ }^{13} \mathrm{C} \mathrm{HMBC} / \mathrm{HMQC}$ spectrum does show crosspeaks between the two $\mathrm{H}^{\prime}$ resonances and their $\mathrm{C} 8$ resonances, but not their $\mathrm{C} 4$ resonances, indicating anti conformations. Thus, absence of one amino group precludes quartet formation but allows a bimolecular anti stacked structure in which the amido and amino protons exchange readily with solvent.

\section{Oligoethyleneoxide tethered c-di-GMP, 3a and $\mathbf{3 b}$}

We have also linked two molecules of $\mathbf{1}$ together with flexible oligoethyleneoxide tethers of four (3a) or twelve (3b) units (Fig. 1), thereby constraining their interactions. Their syntheses 
and 1D NMR spectra are described in the Supporting Information, and their UV and CD data are presented below.

UV Melts (Fig. 10A)—UV melting profiles at $250 \mathrm{~nm}$ for two different concentrations each of $\mathbf{3 a}$ and $\mathbf{3 b}$ with $\mathrm{Li}^{+}$and $\mathrm{K}^{+}$show hypochromic conformational transitions that have very little concentration dependence. Further, for both tether lengths, the $\mathrm{K}^{+}$forms are only slightly more stable than the $\mathrm{Li}^{+}$forms. The transitions are thus primarily intramolecular and cation independent. The structured forms of $3 \mathbf{b}$ have $\mathrm{T}_{\max }$ values of $24{ }^{\circ} \mathrm{C}$ with $\mathrm{Li}^{+}$and $26{ }^{\circ} \mathrm{C}$ with $\mathrm{K}^{+}$, significantly lower than those of $\mathbf{3 a}$, which have $\mathrm{T}_{\max }$ values of $42{ }^{\circ} \mathrm{C}$ with $\mathrm{Li}^{+}$and $44{ }^{\circ} \mathrm{C}$ with $\mathrm{K}^{+}$. The similar hypochromicity in both metals indicates that the tethers allow intramolecular formation of related stacked structures, while the lower stabilities with the longer tether may be due to entropic factors.

CD Spectra (Fig 10B) - CD spectra for the $\mathrm{Li}^{+}$and $\mathrm{K}^{+}$forms of $\mathbf{3 a}$ and $\mathbf{3 b}$ are nearly identical to each other, and similar to the $\mathrm{CD}$ spectrum of 1 with $\mathrm{Li}^{+}$. The lack of any bands near 215 or $305 \mathrm{~nm}$ shows that the tether precludes formation of guanine quartets at this concentration.

NMR Spectra (Supporting Information)-As with 2, the $1 \mathrm{D}{ }^{1} \mathrm{H}$ and ${ }^{31} \mathrm{P}$ NMR spectra of a $15 \mathrm{mM}$ sample of the $\mathrm{Li}^{+}$form of $\mathbf{3 a}$ are much simpler than those of $\mathbf{1}$. The ${ }^{31} \mathrm{P}$ NMR spectrum shows only three resonances near $-2.0 \mathrm{ppm}$, one for each type of phosphate in the molecule. The ${ }^{31} \mathrm{P}$ NMR spectrum of a $13 \mathrm{mM}$ sample of the $\mathrm{K}^{+}$form also gives three dominant resonances near $-2.0 \mathrm{ppm}$, but smaller clusters of signals are present upfield and downfield as well. The ${ }^{1} \mathrm{H}$ NMR spectrum of the $\mathrm{Li}^{+}$form shows no $\mathrm{H} 1$ signals near $11 \mathrm{ppm}$ or amino signals near 9 and $6.5 \mathrm{ppm}$, signifying their exchange with solvent. Single sharp resonances are present for each of the two types of guanine $\mathrm{H} 8$, one of which is closer to the tether and the other farther away. The $\mathrm{K}^{+}$form also shows two dominant sharp $\mathrm{H} 8$ resonances, but a cluster of several smaller $\mathrm{H} 8$ resonances is also present. Further, there are several small $\mathrm{H} 1$ resonances near 11 $\mathrm{ppm}$ and amino resonances near 9 and $6.5 \mathrm{ppm}$. The UV, CD, and NMR results for $\mathbf{3 a}$ with $\mathrm{Li}^{+}$are consistent with the presence of only a unimolecular self-intercalated structure related to the bimolecular self-intercalated structure of $\mathbf{1}, \mathrm{B} a$. With $\mathrm{K}^{+}$, the results support the presence of a mixture with the major component being the self-intercalated structure, but with small amounts of quartet complexes also present. Since the concentration of $\mathbf{3 a}$ with $\mathrm{K}^{+}(26 \mathrm{mM}$ in terms of guanine) is similar to that of $\mathbf{1}$ with $\mathrm{K}^{+}$( $37 \mathrm{mM}$ in guanine), we conclude that the tether makes formation of a quartet structure significantly more difficult, but allows the selfintercalated structure to readily form.

\section{Discussion}

Based on the UV, CD, and NMR data presented above and in our earlier report, ${ }^{24}$ we propose that c-di-GMP can adopt five different but related structures, all participating in an equilibrium that is sensitive to both concentration of $\mathbf{1}$ and the metal present. The cartoons at the bottom of Figure 5 depict these five structures: an anti bimolecular self-intercalated complex, syn and anti versions of a tetramolecular quartet complex, and syn and anti versions of an octamolecular self-intercalated quartet complex. The UV concentration dependence and hypochromicity, as well as the strong $\mathrm{CD}$ spectra, demonstrate the presence of intermolecular guanine stacking. At dilute concentrations with $\mathrm{Li}^{+}, \mathrm{Na}^{+}, \mathrm{Cs}^{+}$, or $\mathrm{Mg}^{2+}, \mathbf{1}$ forms the self-intercalated bimolecular complex that had been found in crystal structures reported for $\mathbf{1}$ in the presence of $\mathrm{Mg}^{2+}$ or $\mathrm{Co}^{2+, 22,23}$ as well as for $\mathbf{1}$ associated with its cyclase from Caulobacter crescentus. ${ }^{7}$ At the higher NMR concentrations with $\mathrm{Li}^{+}$, single $\mathrm{H} 8$ and ${ }^{31} \mathrm{P}$ resonances are seen from this structure. Although this complex has two different types of phosphates and guanines (inner and outer), and the amido H1s and aminos of the inner guanines may be oriented so as to form hydrogen bonds with a phosphate of its partner, our data are consistent with this self-intercalated structure being in fast exchange on the NMR timescale with an unstructured form. Thus no amido or 
amino resonances are present and only single $\mathrm{H} 8, \mathrm{H}^{\prime}$, and ${ }^{31} \mathrm{P}$ resonances are observed. The lack of positive NOE crosspeaks and the relatively large translational diffusion rate support the lower molecular weight of a bimolecular complex.

Our data indicate that the tethered c-di-GMP (3a and 3b) as well as c-GMP-IMP (2) are also able to adopt this self-intercalated structure, in spite of the constraints of the tethers and lack of one amino, respectively. Their UV spectra show significant hypochromicity, and the CD spectra of $\mathbf{3 a}$ and $\mathbf{3 b}$ are nearly identical to those of $\mathbf{1}$. The smaller intensity of the $\mathrm{CD}$ spectrum of $\mathbf{2}$ is most likely because of the altered absorption properties of inosine. Both the 1D and 2D NMR data are consistent with the predominant presence of this self-intercalated structure in the $\mathrm{Li}^{+}$and $\mathrm{K}^{+}$forms of $\mathbf{2}$ and $\mathbf{3 a}$.

At low concentrations of $\mathbf{1}$ with $\mathrm{K}^{+}, \mathrm{Rb}^{+}$, and $\mathrm{NH}_{4}{ }^{+}$, our $\mathrm{UV}$ and $\mathrm{CD}$ data strongly support the presence of one or more additional structures containing guanine quartets. The UV melt of the $\mathrm{K}^{+}$form of 1 at $250 \mathrm{~nm}$ displays two transitions, and its melt at $305 \mathrm{~nm}$ shows characteristics of oligodeoxynucleotides containing quartets with syn conformations. The CD spectra with these metals display new bands at 215 and $309 \mathrm{~nm}$ that are slow to appear and diminish, consistent with a higher molecularity. At the higher NMR concentrations of the $\mathrm{K}^{+}$form, ${ }^{1} \mathrm{H}$ and ${ }^{31} \mathrm{P}$ NMR resonances distinct from those corresponding to the bimolecular structure persist at $55^{\circ} \mathrm{C}$. The ${ }^{1} \mathrm{H}$ NMR spectra, both $1 \mathrm{D}$ and $2 \mathrm{D}$, are consistent with two major structures, both of which have similar and relatively high molecular weights. One has two sets of H8, H1', and ${ }^{31} \mathrm{P}$ resonances, to which we can assign anti conformations, and the other has only one set to which we can assign the syn conformation. The NMR spectra also show two minor structures with similar and relatively smaller molecular weights that are still greater than the bimolecular form, one of which is anti and one of which is syn.

In Wang's reports on the self-intercalated crystal structure of 1 with $\mathrm{Mg}^{2+}$ and $\mathrm{Co}^{2+},{ }^{23}$ he had speculated about the possibility of its rearrangement to a cage-like complex of four molecules of $\mathbf{1}$ containing two parallel guanine quartets $7 \AA$ apart (bottom of Figure 5, center). Although he described only an all-anti version, it might also occur in an all-syn version, and our data support the presence of these two tetramolecular quartet structures as minor components in the $\mathrm{K}^{+}$form of $\mathbf{1}$ at high concentrations. However, if two such all-anti or all-syn quartet complexes (a total of eight molecules of $\mathbf{1}$ ) were able to self-intercalate, they should be stabilized by favorable stacking ( $3.5 \AA$ apart) and additional interactions with the $\mathrm{K}^{+}$ions (bottom of Figure 5 , right). The presence of inner and outer guanosines would account for the two sets of NMR resonances in the all-anti form, in which models show that one set of $\mathrm{H} 8$ atoms appears to be significantly closer to nearby phosphates than the other. In the all-syn form, models show the H8 atoms all appear to be in more similar environments, which may explain the failure to observe more than one set of resonances at the field strength we used. Presumably, these large octamolecular complexes would most easily form by gradual association and readjustment of four of the self-intercalated bimolecular structures.

A slow equilibrium would exist among these five different complexes at high concentrations of $\mathbf{1}$, with $\mathrm{K}^{+}$highly favoring the two octamolecular complexes. Since the smaller, less easily dehydrated $\mathrm{Li}^{+}$is less able to stabilize quartets, the resulting mixture has approximately similar amounts of the bimolecular, the two tetramolecular, and the two octamolecular complexes. Although $\mathrm{Li}^{+}$does not normally stabilize quartet structures, in this case the presence of two aligned guanines in one molecule presents unique circumstances. c-GMP-IMP (2) is unable to form any of these quartet structures because the lack of one amino prevents the full quartet hydrogen bonding. The tethered c-di-GMP (3a, and presumably $\mathbf{3 b}$ ) are restricted in their abilities to form quartet structures with $\mathrm{K}^{+}$. An equilibrium among these five structures for cdi-GMP in a bacterial cell might provide a range of options for the actions of this signaling molecule that would significantly depend on its own concentration as well as local $\mathrm{K}^{+}$ 
concentrations, or the concentrations of other as yet unidentified effectors. The subcellular compartmentalization and gradients that are known to affect the signaling ability of c-diGMP ${ }^{12}$ may be taking advantage of the equilibrium we describe here. As first proposed by Wang, ${ }^{23}$ the tetramolecular complexes may participate in biological pathways by intercalating aromatic groups between the two quartets. We further speculate that the octamolecular complexes may serve as a way to sequester c-di-GMP in an inactive state, with the bimolecular complex providing the active form for signaling. Additional work in our laboratory is underway to further characterize the structural details of these five different complexes, as well as explore in more depth the equilibrium among them.

\section{Conclusion}

We have demonstrated that c-di-GMP, an important bacterial signaling molecule involved in biofilm formation and other pathogenic processes, can adopt a mixture of five different but related structures in ratios that are sensitive to both its concentration and the metal present. A bimolecular self-intercalated structure is dominant at dilute concentrations with $\mathrm{Li}^{+}, \mathrm{Na}^{+}$, $\mathrm{Cs}^{+}$, and $\mathrm{Mg}^{2+}$, while it is accompanied by one or more quartet complexes with $\mathrm{K}^{+}, \mathrm{Rb}^{+}$, and $\mathrm{NH}_{4}{ }^{+}$. At higher concentrations with $\mathrm{K}^{+}$the bimolecular structures associate and rearrange primarily to two stable octamolecular self-intercalated quartet complexes, one all-syn and one all-anti. Two minor tetramolecular quartet complexes are also present, one all-syn and one allanti. At the higher concentrations with $\mathrm{Li}^{+}$the tetramolecular and octamolecular quartet complexes (each with syn and anti versions) are present in approximately equal amounts, along with the bimolecular structure.

\section{Supplementary Material}

Refer to Web version on PubMed Central for supplementary material.

\section{Acknowledgements}

This work was supported by a grant from NIH (EB002809). We thank Kenneth J. Breslauer, James Elliott, and Jens Völker in this Department for assistance with the CD and helpful discussions.

\section{References}

1. Jenal U. Curr Opin Microbiol 2004;7:185-191. [PubMed: 15063857]Romling U, Gomelsky M, Galperin MY. Mol Microbiol 2005;57:629. [PubMed: 16045609]

2. Hall-Stoodley L, Costerton JW, Stoodley P. Nature Rev Microbiol 2004;2:95-108. [PubMed: 15040259]

3. Stewart PS, Costerton JW. Lancet 2001;358:135-138. [PubMed: 11463434]Mah TFC, O'Toole GA. Trends Microbiol 2001;9:34-39. [PubMed: 11166241]

4. Hoffman LR, D'Argenio DA, MacCoss MJ, Zhang Z, Jones RA, Miller SI. Nature (London) 2005;436:1171-1175. [PubMed: 16121184]

5. Paul R, Weiser S, Amiot NC, Chan C, Schirmer T, Giese B, Jenal U. Genes Dev 2004;18:715-727. [PubMed: 15075296]

6. Ryjenkov DA, Tarutina M, Moskvin OV, Gomelsky M. J Bacteriol 2005;187:1792-1798. [PubMed: 15716451]

7. Chan C, Paul R, Samoray D, Amiot NC, Giese B, Jenal U, Schirmer T. Proc Natl Acad Sci USA 2004;101:17084-17089. [PubMed: 15569936]

8. Simm R, Morr M, Kader A, Nimtz M, Romling U. Mol Microbiol 2004;53:1123-1134. [PubMed: 15306016]Tischler AD, Camilli A. Mol Microbiol 2004;53:857-869. [PubMed: 15255898]

9. Bobrov AG, Kirillina O, Perry RD. FEMS Microbiol Lett 2005;247:123-130. [PubMed: 15935569]

10. Galperin MY, Nikolskaya AN, Koonin EV. FEMS Microbiol Lett 2001;203:11-21. [PubMed: 11557134] 
11. Christen M, Christen B, Folcher M, Schauerte A, Jenal U. J Biol Chem 2005;280:30829-30837. [PubMed: 15994307]

12. Romling U. Cell Mol Life Sci 2005;62:1234-1246. [PubMed: 15818467]

13. Ross P, Weinhouse H, Aloni Y, Michaeli D, Weinberger-Ohana P, Mayer R, Braun S, de Vroom E, van der Marel GA, van Boom JH, Benziman M. Nature 1987;325:279-281.

14. Hisert KB, MacCoss M, Shiloh MU, Darwin KH, Singh S, Jones RA, Ehrt S, Zhang Z, Gaffney BL, Gandotra S, Holden D, Murray D, Nathan C. Mol Microbiol 2005;56:1234-1245. [PubMed: 15882417]

15. Tischler AD, Camilli A. Infect Immun 2005;73:5873-5882. [PubMed: 16113306]

16. Waters CM, Bassler BL. Annu Rev Cell Dev Biol 2005;21:319-346. [PubMed: 16212498]

17. Fuqua C, Parsek MR, Greenberg EP. Annu Rev Gen 2001;35:439-468.

18. Kleerebezem M, Quadri LE, Kuipers OP, de Vos WM. Mol Microbiol 1997;24:895-904. [PubMed: 9219998]

19. Pesci EC, Milbank JBJ, Pearson JP, McKnight S, Kende AS, Greenberg EP, Iglewski BH. Proc Natl Acad Sci USA 1999;96:11229-11234. [PubMed: 10500159]Deziel E, Lepine F, Milot S, He J, Mindrinos MN, Tompkins RG, Rahme LG. Proc Natl Acad Sci USA 2004;101:1339-1344. [PubMed: 14739337]

20. Chen X, Schauder S, Potier N, Van Dorsselaer A, Pelczer I, Bassler BL, Hughson FM. Nature (London) 2002;415:545-549. [PubMed: 11823863] McKenzie KM, Meijler MM, Lowery CA, Boldt GE, Janda KD. Chem Commun 2005:4863-4865.

21. Camilli A, Bassler BL. Science 2006;311:1113-1116. [PubMed: 16497924]

22. Egli M, Gessner RV, Williams LD, Quigley GJ, van der Marel GA, van Boom JA, Rich A, Frederick CA. Proc Natl Acad Sci USA 1990;87:3235-3239. [PubMed: 2158107]

23. Liaw YC, Gao YG, Robinson H, Sheldrick GM, Sliedregt LAJM, van der Marel GA, vB AJ, Wang AHJ. FEBS 1990;264:223-227.Guan Y, Gao YG, Liaw YC, Robinson H, Wang AHJ. J Biomol Struct Dyn 1993;11:253-276. [PubMed: 8286055]

24. Zhang Z, Gaffney BL, Jones RA. J Am Chem Soc 2004;126:16700-16701. [PubMed: 15612689]

25. Marky LA, Breslauer KJ. Biopolymers 1987;26:1601-1620. [PubMed: 3663875]

26. Mergny JL, Phan AT, Lacroix L. FEBS Lett 1998;435:74-78. [PubMed: 9755862]

27. Keniry MA. Biopolymers (NAS) 2001;56:123-146.

28. Cantor CR, Fairclough RH, Newmark RA. Biochemistry 1969;8:3610-3617. [PubMed: 5820657]

29. Chantot JF, Haertle T, Guschlbauer W. Biochemie 1974;56:501-507.

30. Pohl FM, Jovin TM. J Mol Biol 1972;67:375-396. [PubMed: 5045303]

31. Scott JF, Zamecnik PC. Proc Natl Acad Sci USA 1969;64:1308-1314. [PubMed: 5271753]Holler E, Holmquist B, Vallee BL, Taneja K, Zamecnik P. Biochemistry 1983;22:4924-4933. [PubMed: 6639937]

32. Hardin CC, Perry AG, White K. Biopolymers (NAS) 2001;56:147-194.Davis JT. Angew Chem Int Ed Engl 2004;43:668-698. [PubMed: 14755695]

33. Jin R, Gaffney BL, Wang C, Jones RA, Breslauer KJ. Proc Natl Acad Sci USA 1992;89:8832-8836. [PubMed: 1528900]

34. Wang Y, Patel DJ. Biochemistry 1992;31:8112-8119. [PubMed: 1525153]Smith FW, Feigon J. Biochemistry 1993;32:8682-8692. [PubMed: 8357810]

35. Wang Y, de los Santos C, Gao X, Greene K, Live D, Patel DJ. J Mol Biol 1991;222:819-832. [PubMed: 1660934]Smith FW, Feigon J. Nature (London) 1992;356:164-1168. [PubMed: 1545871] Wang KY, McCurdy S, Shea RG, Swaminathan S, Bolton PH. Biochemistry 1993;32:1899-1904. [PubMed: 8448147]

36. Cavanagh, J.; Fairbrother, WJ.; Palmer, AG., III; Skelta, NJ. Academic Press, Inc.; San Diego, CA: 1996. p. 289-290.

37. Zhu G, Live D, Bax A. J Am Chem Soc 1994;116:8370-8371.

38. Marlow AL, Mezzina E, Spada GP, Masiero S, Davis JT, Gottarelli G. J Org Chem 1999;64:51165123.

39. Phan AT, Patel DJ. J Am Chem Soc 2003;125:15021-15027. [PubMed: 14653736] 
40. Forman SL, Fettinger JC, Pieraccini S, Gottarelli G, Davis JT. J Am Chem Soc 2000;122:4060-4067. 41. Lapham J, Rife JP, Moore PB, Crothers DM. J Biomol NMR 1997;10:255-262. [PubMed: 9390403] 


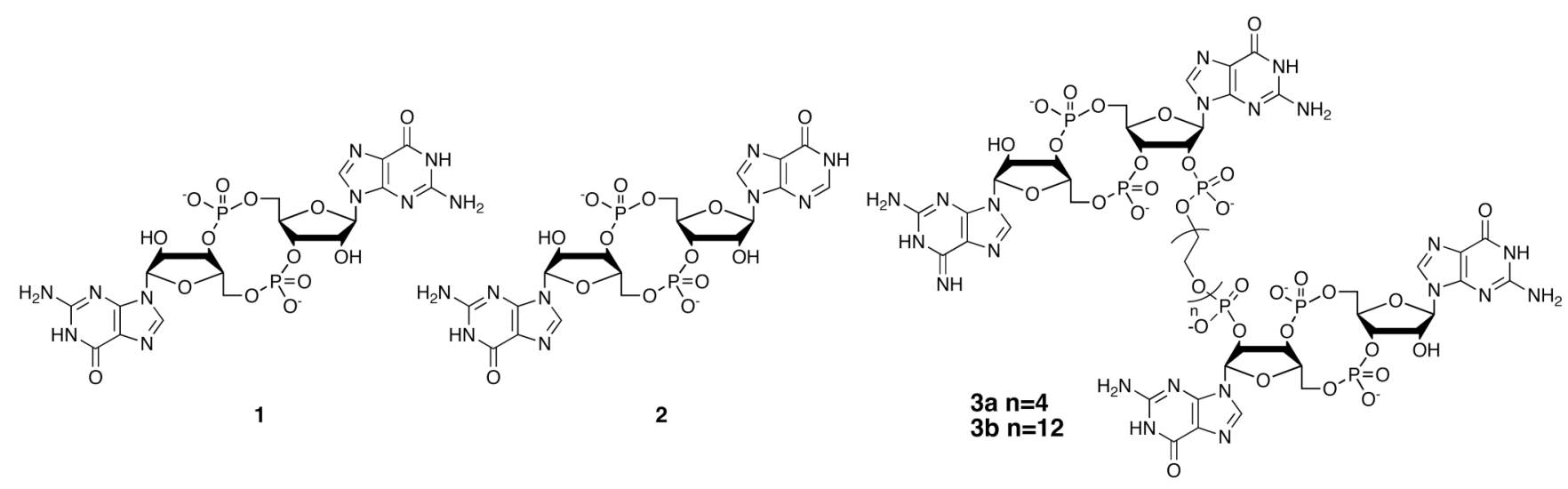

Figure 1.

Structures of c-di-GMP, 1, c-GMP-IMP, 2, and oligoethyleneoxide tethered c-di-GMP, 3a $(\mathrm{n}=4)$ and $\mathbf{3 b}(\mathrm{n}=12)$. 

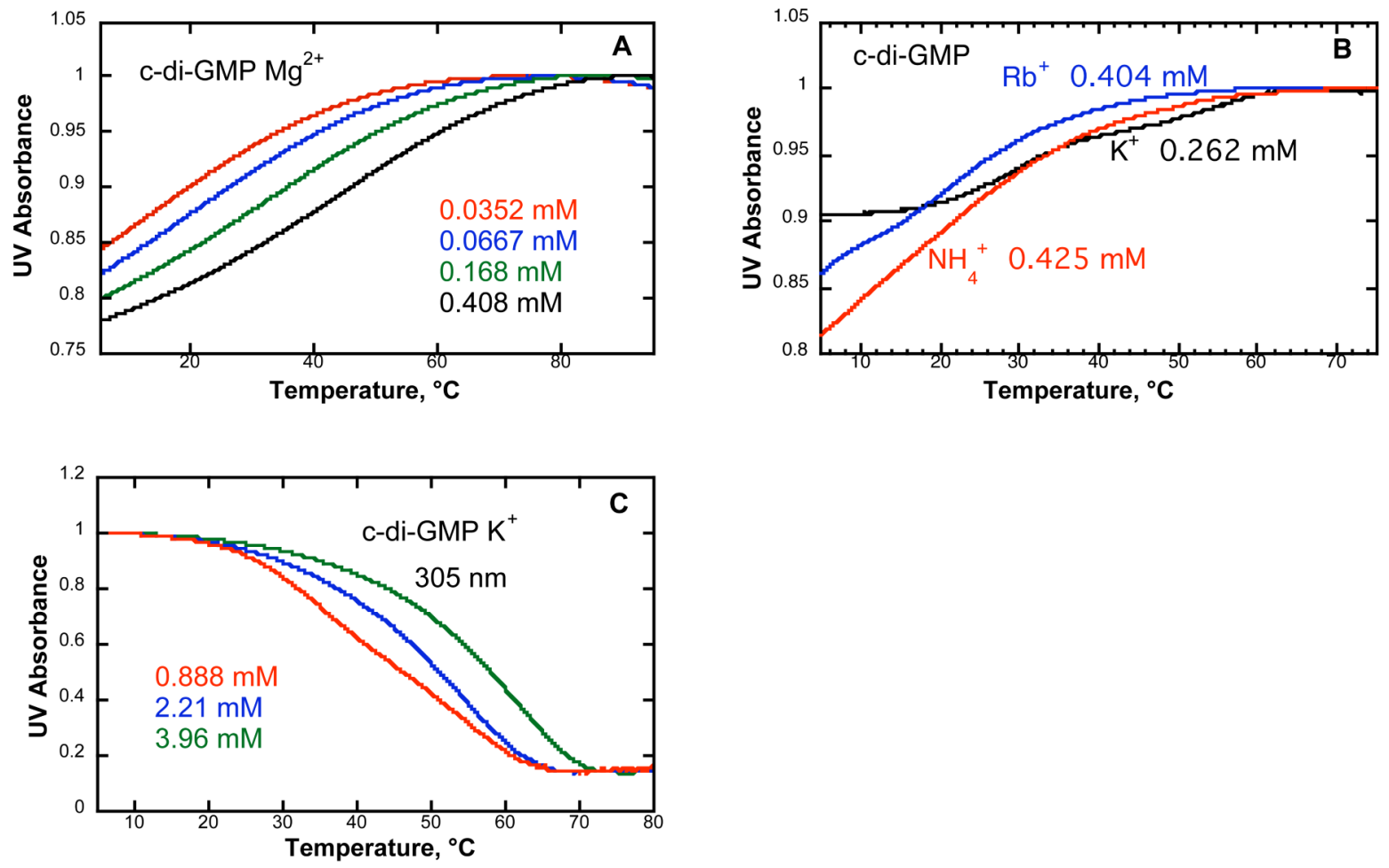

Figure 2.

Normalized UV melting profiles (A) at $250 \mathrm{~nm}$ of four different concentrations of the $\mathrm{Mg}^{2+}$ form of 1 in $10 \mathrm{mM} \mathrm{Mg}(\mathrm{OAc})_{2}$ w ith $0.1 \mathrm{M} \mathrm{MgCl}_{2}, \mathrm{pH} 7.0$, (B) at $250 \mathrm{~nm}$ of the $\mathrm{K}^{+}$(black), $\mathrm{Rb}^{+}$(blue), and $\mathrm{NH}_{4}{ }^{+}$(red) forms of 1 in $10 \mathrm{mM}$ potassium phosphate with $0.1 \mathrm{M} \mathrm{KCl}, 10$ $\mathrm{mM}$ rubidium phosphate with $0.1 \mathrm{M} \mathrm{RbCl}$, and $10 \mathrm{mM}$ ammonium phosphate with $0.1 \mathrm{M}$ $\mathrm{NH}_{4} \mathrm{Cl}$, respectively, all $\mathrm{pH} 7.0$, and (C) at $305 \mathrm{~nm}$ of three different concentrations of the $\mathrm{K}^{+}$form of 1 in $10 \mathrm{mM}$ potassium phosphate with $0.1 \mathrm{M} \mathrm{KCl}$. 

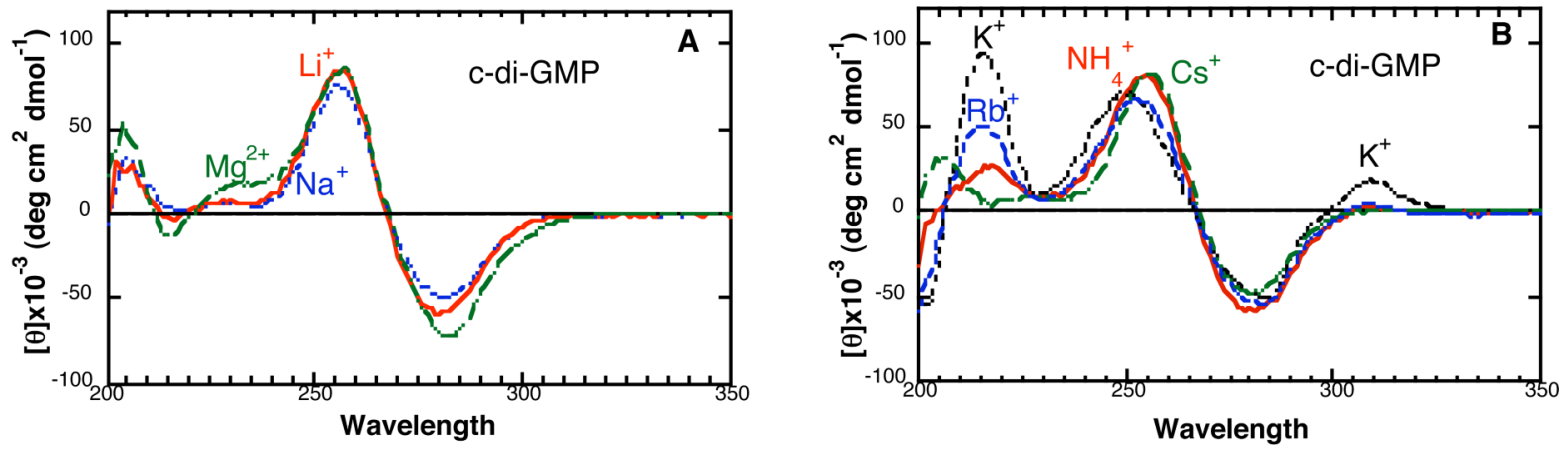

Figure 3.

CD spectra of 1 at $5^{\circ} \mathrm{C}$ in $0.1 \mathrm{~cm}$ cells of (A) $0.384 \mathrm{mM} \mathrm{Li}^{+}$form (red), $0.395 \mathrm{mM} \mathrm{Na}^{+}$form (blue), and $0.437 \mathrm{mM} \mathrm{Mg}^{2+}$ form (green) in $10 \mathrm{mM} \mathrm{LiOAc}$ with $0.1 \mathrm{M} \mathrm{LiCl}, 10 \mathrm{mM}$ sodium phosphate with $0.1 \mathrm{M} \mathrm{NaCl}$, and $10 \mathrm{mM} \mathrm{Mg}(\mathrm{OAc})_{2}$ with $0.1 \mathrm{M} \mathrm{MgCl}_{2}$, respectively, all at $\mathrm{pH}$ 7.0, and (B) $0.409 \mathrm{mM} \mathrm{K}^{+}$form (black), $0.383 \mathrm{mM} \mathrm{Rb}^{+}$form (blue), $0.382 \mathrm{mM} \mathrm{Cs}^{+}$form (green), and $0.378 \mathrm{mM} \mathrm{NH}_{4}{ }^{+}$form (red) in $10 \mathrm{mM}$ potassium phosphate with $0.1 \mathrm{M} \mathrm{KCl,} 10$ mM RbOAc with $0.1 \mathrm{M} \mathrm{RbCl}, 10 \mathrm{mM} \mathrm{CsOAc}$ with $0.1 \mathrm{M} \mathrm{CsCl}$, and $10 \mathrm{mM} \mathrm{NH}_{4} \mathrm{OAc}$ with $0.1 \mathrm{M} \mathrm{NH}_{4} \mathrm{Cl}$, respectively, all at $\mathrm{pH}$ 7.0. 

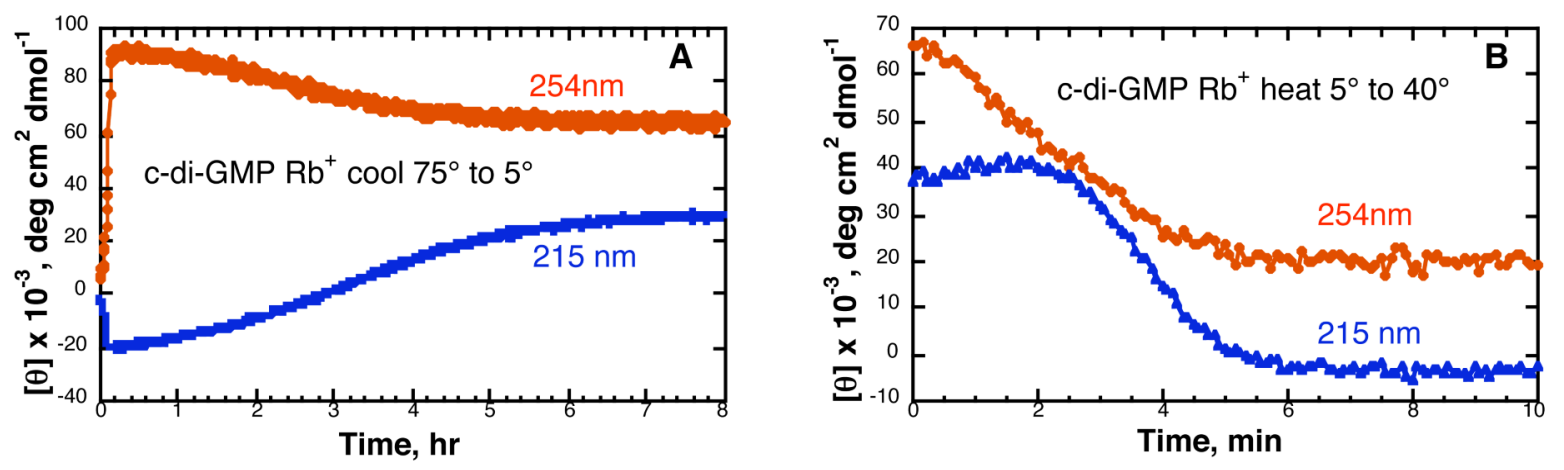

Figure 4.

Plots of molar elliptici at a given wavelength as a function of time after (A) cooling or (B) heating pre-equilibrated samples of the $\mathrm{Rb}^{+}$form of 1 in a $0.1 \mathrm{~cm}$ cell. 


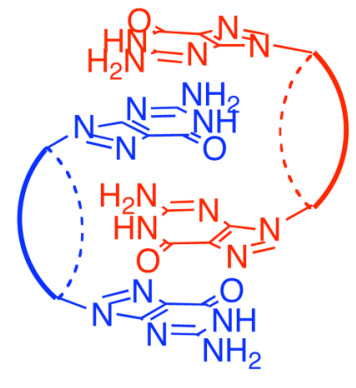

bimolecular

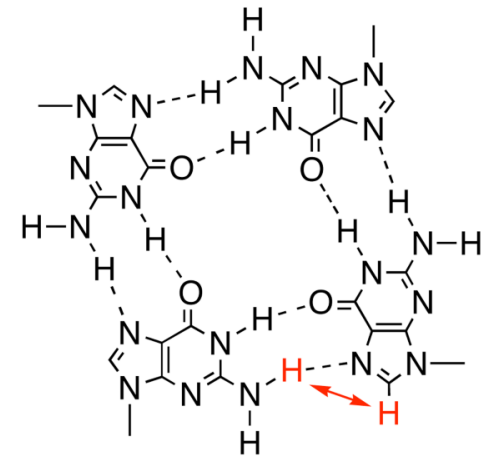

quartet

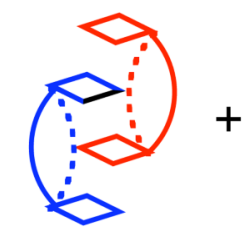

bimolecular anti (Ba)

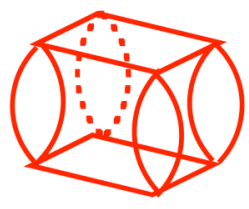

tetramolecular all-syn (Ts) and all-anti (Ta)

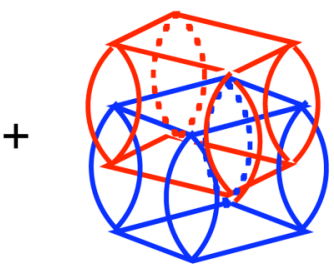

octamolecular all-syn (Os) and all-anti (Oa)

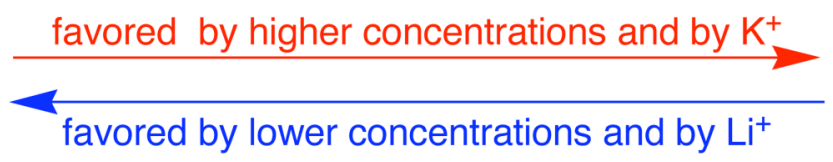

Figure 5.

Cartoons of proposed structures of $\mathbf{1}$ 


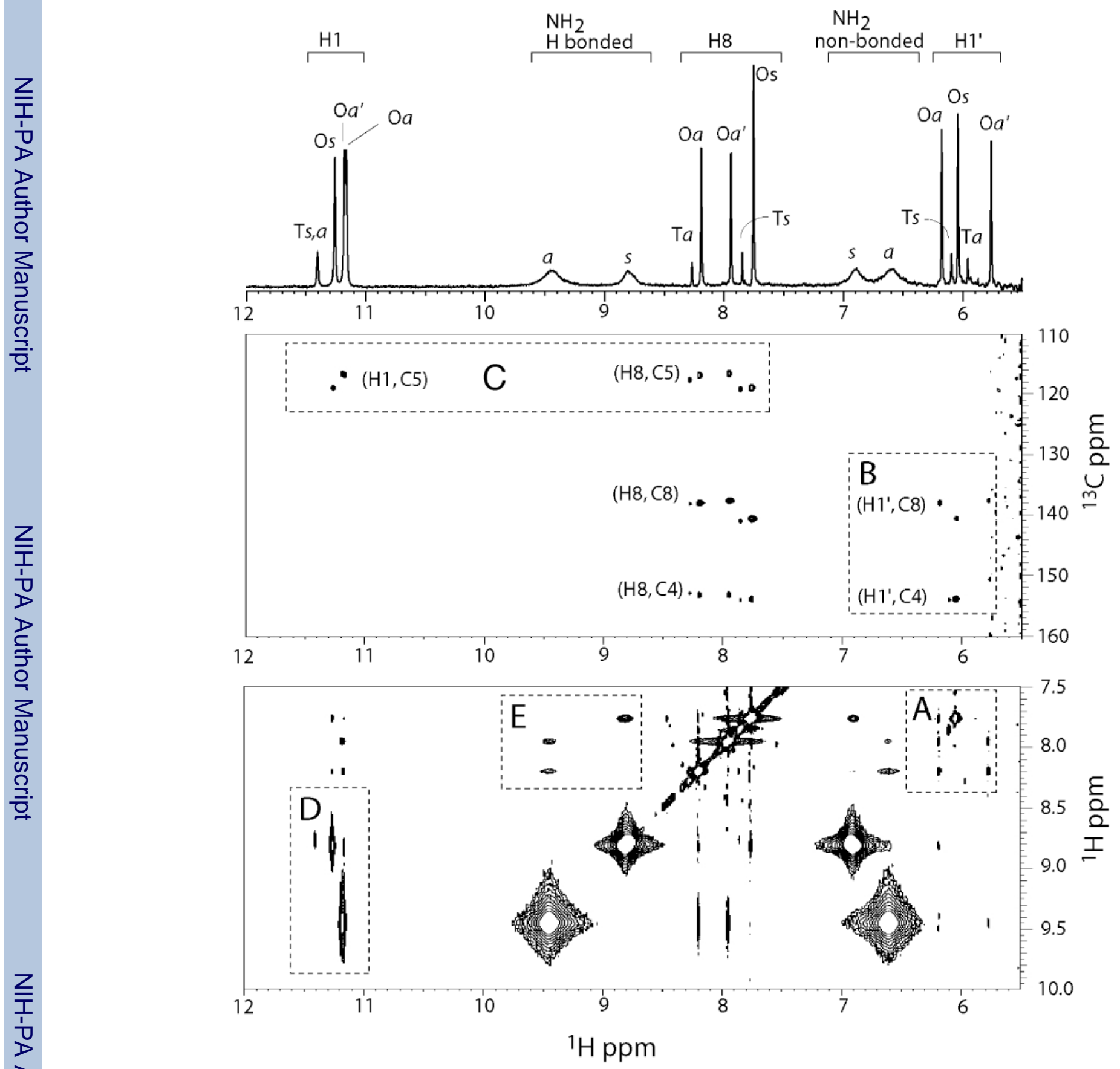

Figure 6.

NMR spectra of a $37 \mathrm{mM}$ sample of the $\mathrm{K}^{+}$form of $\mathbf{1}$ in $0.1 \mathrm{M} \mathrm{KCl}$ in $90 / 10 \mathrm{H}_{2} \mathrm{O} / \mathrm{D}_{2} \mathrm{O}$ at 25 ${ }^{\circ} \mathrm{C}$, with its $1 \mathrm{D}{ }^{1} \mathrm{H}$ spectrum at the top, a portion of its superimposed ${ }^{1} \mathrm{H}_{-}{ }^{13} \mathrm{C} \mathrm{HMBC} / \mathrm{HMQC}$ spectrum at the center, and a portion of its ${ }^{1} \mathrm{H}-{ }^{1} \mathrm{H}$ NOESY spectrum at the bottom. Regions of interest are labeled to correspond with the text. 


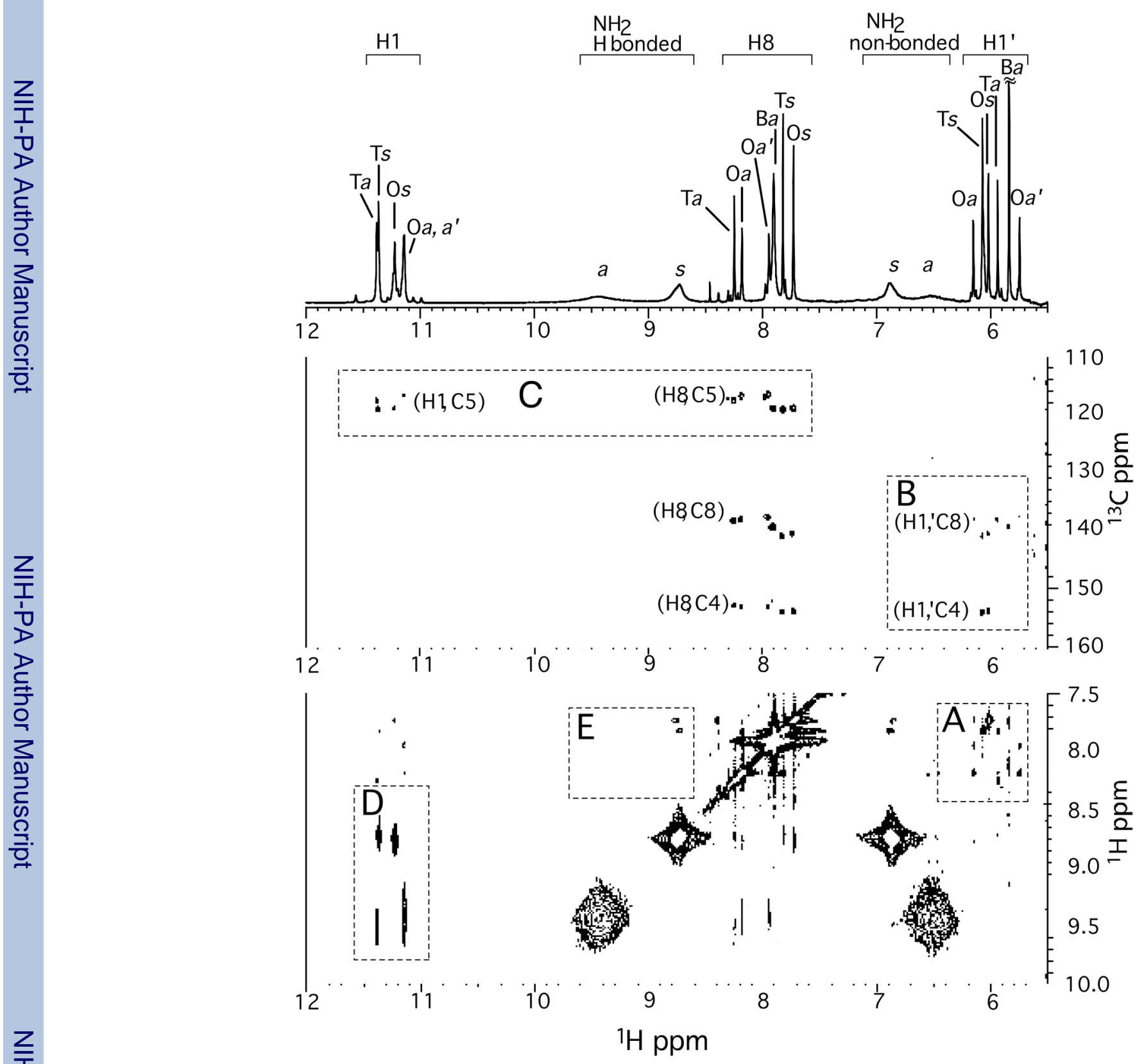

Figure 7.

NMR spectra of a $33 \mathrm{mM}$ sample of the $\mathrm{Li}^{+}$form of 1 in $0.1 \mathrm{M} \mathrm{LiCl}$ in $90 / 10 \mathrm{H}_{2} \mathrm{O} / \mathrm{D}_{2} \mathrm{O}$ at pH 7 at $25{ }^{\circ} \mathrm{C}$, with its ${ }^{1} \mathrm{H} 1 \mathrm{D}$ spectrum at the top, a portion of its superimposed ${ }^{1} \mathrm{H}-{ }^{13} \mathrm{C} \mathrm{HMBC} /$ HMQC spectrum at the center, and a portion of its ${ }^{1} \mathrm{H}-{ }^{1} \mathrm{H}$ NOESY spectrum at the bottom. Regions of interest are labeled to correspond with the text. 

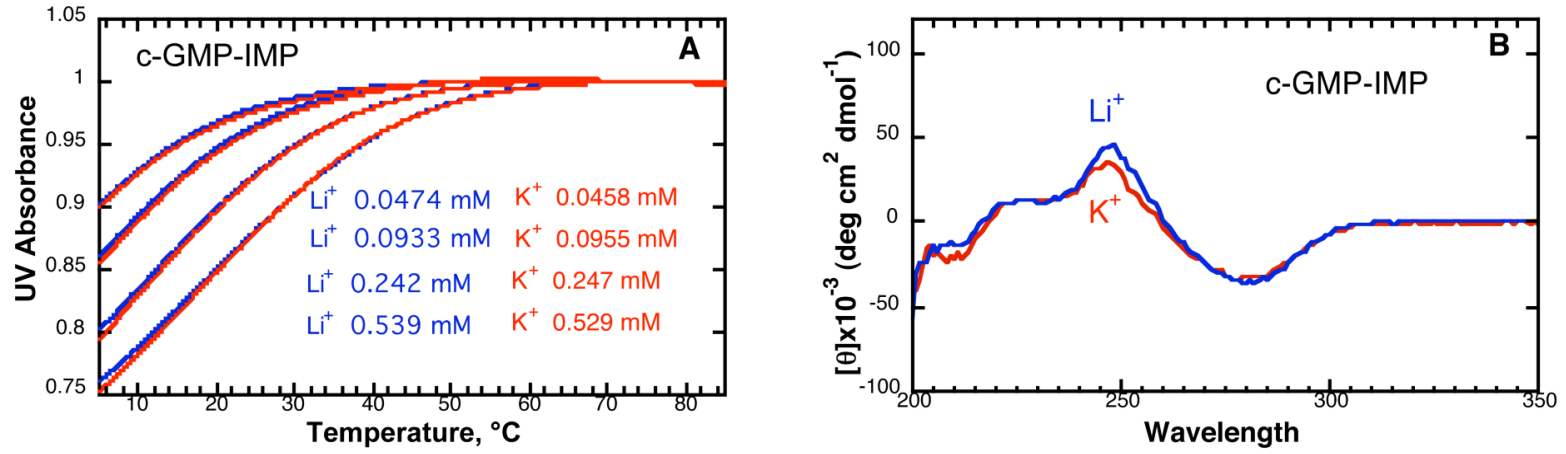

Figure 8.

(A) Normalized UV melting profiles at $250 \mathrm{~nm}$ of four different concentrations of $\mathrm{Li}^{+}$(blue) and $\mathrm{K}^{+}$(red) forms of 2 in $10 \mathrm{mM} \mathrm{LiOAc}$ with $0.1 \mathrm{M} \mathrm{LiCl}$, and $10 \mathrm{mM}$ potassium phosphate with $0.1 \mathrm{M} \mathrm{KCl}$, respectively, both $\mathrm{pH} 7.0$, and (B) $\mathrm{CD}$ spectra at $5^{\circ} \mathrm{C}$ in $0.1 \mathrm{~cm}$ cells of 0.537 $\mathrm{mM} \mathrm{Li}^{+}$form (blue) and $0.544 \mathrm{mM} \mathrm{K}^{+}$form (red) of 2 in $10 \mathrm{mM} \mathrm{LiOAc}$ with $0.1 \mathrm{M} \mathrm{LiCl}$, and $10 \mathrm{mM}$ potassium phosphate with $0.1 \mathrm{M} \mathrm{KCl}$, respectively, both at $\mathrm{pH}$ 7.0. 


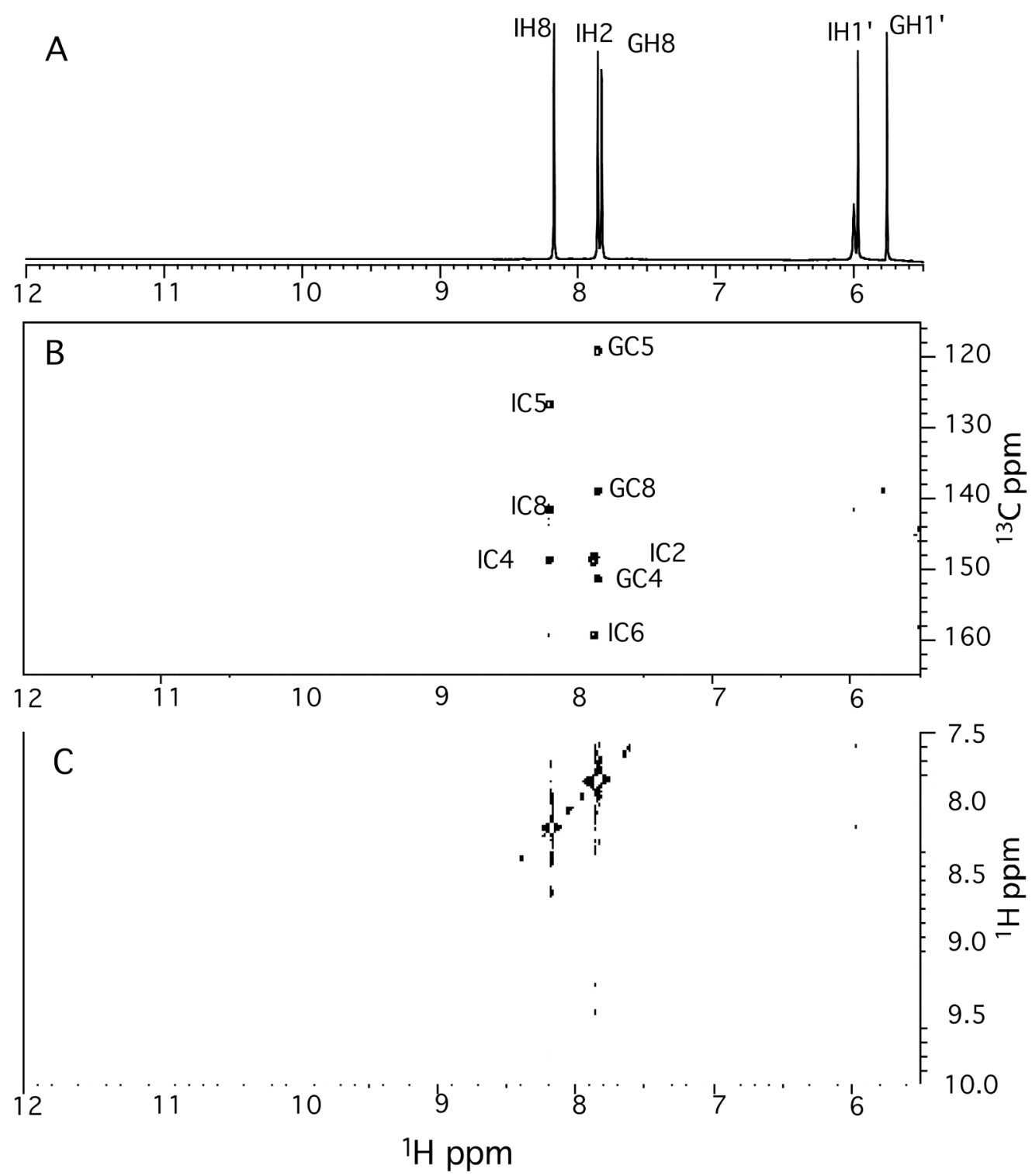

Figure 9.

NMR spectra of a $60.8 \mathrm{mM}$ sample of the $\mathrm{K}^{+}$form of 2 in $90 / 10 \mathrm{H}_{2} \mathrm{O} / \mathrm{D}_{2} \mathrm{O}$ at $25^{\circ} \mathrm{C}$, with its $1 \mathrm{D}$ spectrum at the top, a portion of its superimposed ${ }^{1} \mathrm{H}-{ }^{13} \mathrm{C} \mathrm{HMBC} / \mathrm{HMQC}$ spectrum at the center, and a portion of its ${ }^{1} \mathrm{H}-{ }^{1} \mathrm{H}$ NOESY NMR spectrum at the bottom. 

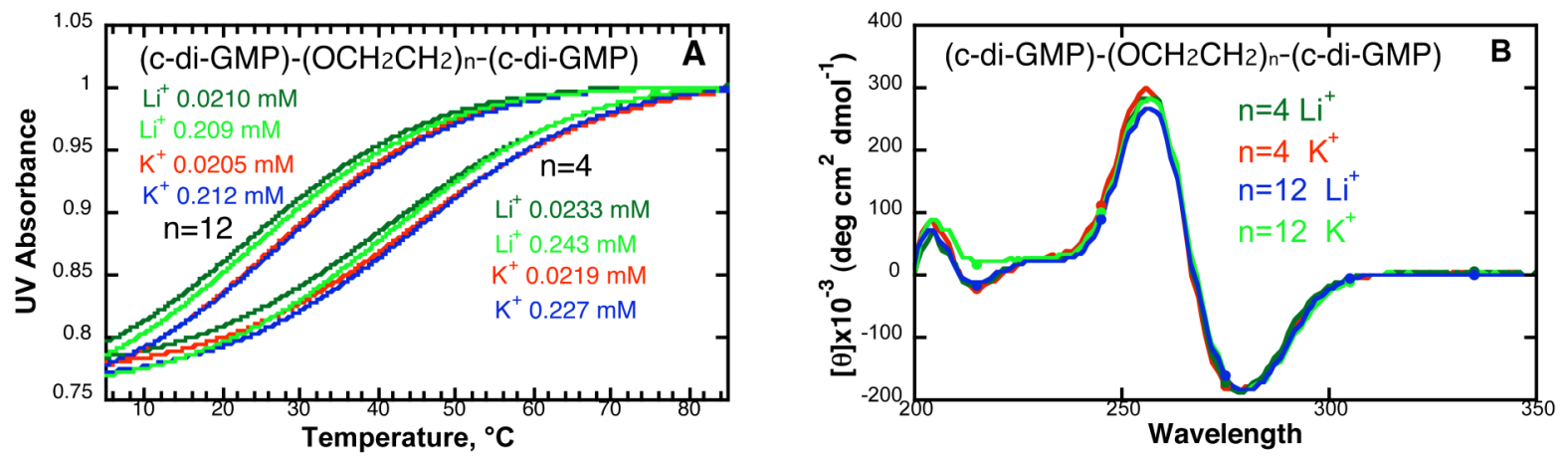

Figure 10.

(A) Normalized UV melting profiles at $250 \mathrm{~nm}$ of two different concentrations each of the $\mathrm{Li}^{+}$(dark and light green) and $\mathrm{K}^{+}$(red and blue) forms of $\mathbf{3 a}$ and $\mathbf{3 b}$ in $10 \mathrm{mM} \mathrm{LiOAc}$ with 0.1 $\mathrm{M} \mathrm{LiCl}$, and $10 \mathrm{mM}$ potassium phosphate with $0.1 \mathrm{M} \mathrm{KCl}$, respectively, both $\mathrm{pH} 7.0$, and (B) $\mathrm{CD}$ spectra at $5^{\circ} \mathrm{C}$ in $0.1 \mathrm{~cm}$ cells of $0.227 \mathrm{mM} \mathrm{Li}^{+}$form (dark green) and $0.227 \mathrm{mM} \mathrm{K}^{+}$form (red) of $3 \mathbf{a}$ in $10 \mathrm{mM} \mathrm{LiOAc}$ with $0.1 \mathrm{M} \mathrm{LiCl}$, and $10 \mathrm{mM}$ potassium phosphate with $0.1 \mathrm{M}$ $\mathrm{KCl}$, respectively, and $0.209 \mathrm{mM} \mathrm{Li}^{+}$form (blue) and $0.212 \mathrm{mM} \mathrm{K}^{+}$form (light green) of $\mathbf{3 b}$ in $10 \mathrm{mM} \mathrm{LiOAc}$ with $0.1 \mathrm{M} \mathrm{LiCl}$, and $10 \mathrm{mM}$ potassium phosphate with $0.1 \mathrm{M} \mathrm{KCl}$, respectively, all at $\mathrm{pH} 7.0$. 